CAHIER DE RECHERCHE \#1806E

WORKING PAPER \#1806E

Département de science économique

Department of Economics

Faculté des sciences sociales

Université d'Ottawa

Faculty of Social Sciences

University of Ottawa

\title{
Social Capital and Having a Regular Family Doctor: Evidence from Longitudinal Data*
}

Hana Bataineh ${ }^{\dagger}$, Rose Anne Devlin, and Vicky Barham ${ }^{\S}$

June 2018

\footnotetext{
* The analysis presented in this paper was conducted at the COOL RDC, part of the Canadian Research Data Centre Network (CRDCN). The services and activities provided by the COOL RDC are made possible by the financial or in-kind support of the SSHRC - Social Sciences and Humanities Research Council of Canada, the CIHR - Canadian Institutes of Health Research, the CFI - Canada Foundation for Innovation, Statistics Canada, Carleton University, the University of Ottawa and the Université du Québec en Outaouais. The views expressed in this paper do not necessarily represent the CRDCN's or that of its partners. We thank Catherine Deri Armstrong, Gilles Grenier, Mehdi Ammi and Logan McLeod for their comments on earlier work upon which this paper is based.

† Department of Economics, University of Ottawa, 120 University Private, Ottawa, Ontario, Canada, K1N 6N5; e-mail: hbataine@uottawa.ca.

₹ Corresponding Author; Department of Economics, University of Ottawa, 120 University Private, Ottawa, Ontario, Canada, K1N 6N5; e-mail: radevlin@uottawa.ca.

$\S$ Department of Economics, University of Ottawa, 120 University Private, Ottawa, Ontario, Canada, K1N 6N5; e-mail: vbarham@uottawa.ca.
} 


\begin{abstract}
Evidence shows that access to a regular family doctor increases the likelihood of regular care; but about $15 \%$ of the Canadian population does not have access to a regular family doctor. We are the first to examine if the presence of individual social capital (e.g., tangible support, friends and family) increases the likelihood of having a regular family doctor. Using the Canadian National Population Health longitudinal survey (1994 to 2010) and a dynamic random effects model (with and without endogenous initial conditions) we find robust evidence of a statistically significant and positive causal relationship between social capital and the probability of having a regular family doctor. Since past access to a family doctor is a strong predictor of both current and future access, we show that social capital is much more important in helping individuals find a family doctor than for keeping one.
\end{abstract}

Key words: Social Capital; Social Networks; Regular Family Doctor; National Population Health Survey.

JEL Classification: I10; I12 


\section{Introduction}

A significant portion of health care is publicly funded in Canada. Its provision and funding is primarily a provincial responsibility, but Federal funds are available contingent on the Provinces adhering to a set of criteria designed to ensure coherence across jurisdictions (Canada Health Act (R.S.C., 1985, c. C-6). ${ }^{1}$ Anywhere in Canada it is 'free' to visit a general practitioner and most specialists. Family physicians are essentially the gatekeepers to specialists; without a family physician referral, it is almost impossible to see a specialist. For the most part, individuals are attached to a family physician or to a practice clinic. Usually, the physician has to 'accept' a client as a patient, once accepted the physician becomes the client's regular family doctor. Except for clinics expressly set up on a 'walk-in' basis, normally the patient has to be attached to the family doctor (or practice) before the patient can have a consultation. The past couple of decades have witnessed frustration with this system because of the number of individuals without a regular family doctor.

Approximately 15 percent of the Canadian population aged 12 years and older reported in 2014 that they did not have a regular family doctor. Those aged 20 to 34 are the least likely to have one, whereas those aged 65 and older are the most likely (Statistics Canada, 2014). A regular family physician is an important determinant of access to health care services (Dunlop et al., 2000; Sanmartin et al., 2004) and is associated with increased use of preventive care (Lambrew et al., 1996; McIssac et al., 2001; Morales et., 2004) and fewer emergency department visits (Orr et al., 1991). One strategy to improve access, and mitigate against the rising costs in health care, is by promoting affiliation with a regular family doctor. Social capital has been linked to having a

\footnotetext{
${ }^{1}$ Retrieved from: http://laws-lois.justice.gc.ca/eng/acts/C-6/page-1.html.
} 
regular family doctor (Devlin and Rudolph-Zbarsky, 2014) and to using physician services (e.g., Deri, 2005; Laporte et al., 2008; Samek et al., 2012).

Social capital can be measured either at the community or at the individual level. To measure social capital at the community level, researchers have relied on community-wide measures like employment per capita and the presence of social services organizations (e.g., Scheffler et al., 2008). In this paper, we focus on individual level social capital which has been measured in the literature in terms of the number or presence of relatives and friends (Rose, 2000), family structure (Putnam, 2000; Folland, 2006), membership in formal or informal groups (Rose, 2000) and trust (Barefoot et al., 1998; Veenstra, 2000). Individual social capital may enhance the acquisition of knowledge about available health care, increase awareness that treatment is needed, facilitate transportation to health care facilities, and be a source of financial and other resources to the individual (Deri, 2005; Laporte et al., 2008; Miltiades and Wu, 2008; Devillanova; 2008; Averett et al., 2014).

Four Canadian studies are of particular interest. Deri (2005) examines the effect of social networks on health care utilization decisions, focusing on networks based on a common language other than English or French. She finds that networks affect health care utilization behavior. Living in areas with high numbers of people who belongs to the same language group who themselves are heavy users of the health care system increases access to health care for individuals in that linguistic network - the "information"” channel. But if they were low users of the health care system, this has the opposite effect - the "norm" channel.

The role of both community and individual social capital in Canada is highlighted by Laporte et al. (2008), who investigate the relationships between aging, social capital and health care utilization. They show that higher community or lower individual social capital is associated 
with a lower probability for GP visits and with a higher probability of hospital utilization by seniors. Individual social capital may serve as an enabling factor to access health services, whereas community social capital may obviate the need for some physician services like caring services.

Samek et al. (2012) study the difference in the impact of social capital on the use of general practitioners (GP) between immigrants and non-immigrants residing in the province of Ontario, Canada. Surprisingly, community social capital is not a significant influence on the use of general practitioners for any of the estimations, however tangible support is associated with more general practitioner visits by non- immigrants, affection support is associated with fewer visits made by non-immigrants. Finally, Devlin and Rudolph-Zbarsky (2014) use Canadian cross-sectional data and find that the sense of belonging to the local community is positively correlated with the likelihood of having a regular family doctor.

Available evidence, however, does not address the question as to whether social capital is simply associated with access to health care or whether its effect is causal. We are able to fill a part of this gap by using the longitudinal National Population Health Survey (NPHS) and examining the role of social capital in accessing a regular family physician. Longitudinal data allow us to examine causality by controlling for time-invariant unobserved effects, like personal preferences or differences in attitudes towards health care. We employ a dynamic model to explore whether past access to a regular family doctor predicts current access. Lagged measures of social support control for possible reverse causality: that access to a regular family doctor might cause individuals to have more social support, and to account for the possibility that social capital affects access to health care with delay.

We find robust evidence of a positive causal link between social capital and the likelihood of having a regular family doctor. Not surprisingly, past access to a family doctor is an important 
determinant of current access and so the factors influencing having a regular family doctor in the past have repercussions for continued access today. Social capital factors exert much stronger impacts on having a regular family doctor for those without one in the previous period relative to those with one in the previous period. Social capital also exerts a larger influence on males than females, and on younger adults as compared to older ones.

\section{Methodology}

A first challenge is to capture social capital. We consider several measures of individual social capital: the number of close friends and relatives, living arrangements or family structure (as a proxy for the availability of immediate care), and two indices that assess the level and the strength of affection and tangible support. Lagged values of these measures account for possible reverse causality between access to regular family doctor and social capital; they also account for the possibility that social capital may require time to affect access to health care. A vector of observable characteristics includes socio-demographic variables (gender, age, education level and immigrant status), as well as variables such as total household annual income, the number of chronic conditions, life style indicators (smoking, alcohol drinking and physical activity), geographic location (urban or rural, and the province of residence) and a time trend.

In the problem at hand, we also expect unobservable individual factors to affect the probability of having a family doctor. These may reflect differences in personal preferences, time preference, and preferences and attitudes to health care. An advantage of having a longitudinal data set is that it is possible to control for these unobserved factors.

A static random effects approach allows us to determine the extent to which an individual's characteristics, both observed and unobserved, affect the likelihood of having access to a regular family doctor. But a static model ignores possible dynamic effects, including the fact that past 
access to a family doctor may predict current access status, other things being equal. Incorporating both dynamic elements and unobserved heterogeneity into a model would allow us to examine persistence in accessing family doctors and to separate the effects of observed and unobserved characteristics on the likelihood of accessing a family doctor.

To capture the dynamic effect of past access to a family doctor on current access status, a lagged dependent variable (dynamic random effects model) approach can be used allowing us to see whether or not having a family doctor in period $t-1$ affects the likelihood of having one in period $t$. This approach has been used to study the dynamics of unemployment (for example, Arulampalam and Stewart, 2000; Stewart, 2007), poverty (Biewen, 2004), low pay persistence (Clark and Kanellopoulos, 2013), social assistance (Hanson et al., 2006), persistence in medical care use (Kohn and Liu, 2013) and the dynamics of health in a British health household panel survey (Contoyannis et al., 2004).

The dynamic random effects estimating equation is:

$$
y_{i t}=\beta_{1}(y)_{i t-1}+\beta_{2}(S c)_{i t-1}+\beta_{3}(X)_{i t}+v_{i}+\mu_{i t}
$$

where $y_{i t}$ is a is a dichotomous variable equal to one when individual $i$ has a regular family doctor in period $t$ and zero otherwise; $y_{i t-1}$ is the status of access to a family doctor in the previous cycle, $S c_{i t}$ is an indicator of social capital; $X_{i t}$ is a vector of observable characteristics; $v_{i}$ represents all other individual-specific determinants of access to a family doctor not captured by $X$, and $\mu_{i t}$ is the error term. State dependence, that is, the effect of having a family doctor in the previous period on the likelihood that a given individual has access to a family doctor in the current period, is measured through the coefficient on the lagged dependent variable $y_{i t-1}$ : the larger the value $\beta_{1}$, the greater the degree of state dependence or persistence in accessing a family doctor. One could estimate equation (1) directly using a fixed effects model capable of eliminating all time invariant 
differences among individuals. But in non-linear panel data models, the use of fixed effects may result in a dynamic panel bias because the number of parameters grows quickly with the number of observations; the parameter estimates may not converge to their true values as the sample size increases (Nickell, 1981; Greene and Hensher, 2010). Estimating the dynamic random effects model is further complicated by the initial conditions problem, namely the potential impact of what happened prior to the sample information being collected on current observations. This problem requires an additional assumption about the relationship between the initial observations $y_{i \text { Init }}$ and unobserved heterogeneity $\left(\alpha_{i}\right)$. If $y_{i}$ Init is independent of $\alpha_{i}$, equation (1) can be estimated using a standard random effects probit (Stewart, 2007). If, however, the initial conditions are correlated with $\alpha_{i}$ - as is likely to be the case here - then this will induce correlation between the error term and the lagged dependent variable in equation (1). Using the standard random effects procedure may lead to overstating $\beta_{1}$, the degree of state dependence (persistence) (e.g., Heckman, 1981; Chay and Hyslop, 2000; Wooldridge, 2005; Stewart, 2007).

We follow Mundlak (1978), Chamberlain (1984) and Wooldridge (2005) in allowing for correlation between the unobserved effects and $X_{i t}$ by assuming that $v_{i}=\beta_{5} \bar{x}_{i}+\alpha_{i}$ where $\alpha_{i}$ is distributed $\left(0, \sigma 2_{\alpha}\right)$ and assumed to be independent of $X_{i t}$ and $\mu_{i t}$ for all $i, t$. Substituting into equation (2) gives:

$$
y^{*}{ }_{i t}=\beta_{1}(y)_{i t-1}+\beta_{2}(S c)_{i t-1}+\beta_{3}\left(y_{i \text { Init }}\right)+\beta_{4}(X)_{i t}+\beta_{5}\left(\bar{x}_{i}\right)+\alpha_{i}+\mu_{i t}
$$

The $\bar{x}_{i}$ vector is typically considered as the longitudinal average for each individual of each characteristic in the vector $X_{i t}$ (except time-variant variables like age) - we call this the Dynamic $\mathrm{RE}$ - endogenous conditions model.

We therefore report two different empirical models. The first, using equation (1), is a dynamic random effects (Dynamic RE) model that accounts for unobserved heterogeneity but 
assumes exogenous initial conditions; the second, using equation (2), is a dynamic random effects model that allows for correlations between individual unobserved characteristics and $\mathrm{x}$-variables (Dynamic RE -- endogenous). We also run these models on data separated by sex.

\section{The NPHS Dataset}

The National Population Health Survey (NPHS) conducted by Statistics Canada collects detailed information about the health of Canadians, their health care use and socio-demographic factors. Starting in 1994/1995, the survey was conducted every two years until 2010/2011, after which it was discontinued. The 1994/95 and 1996/97 cycles do not contain information on the same indictors of social support contained in subsequent cycles and hence were eliminated. The analysis is thus restricted to cycles 3 to 9 (seven cycles: 1998/99 to 2010/2011), to respondents aged 18 or older in cycle 3 (losing 15,379 person-year observations) and to observations with complete information. To implement the dynamic model, we need respondents to have participated in at least two consecutive cycles, leading to a further loss of 3,399 person-year observations. The final sample is an unbalanced panel of 10,403 individuals, consisting of 41,022 person-year observations; 3,356 individuals, or about 30 percent of the sample, are observed in every cycle.

The dependent variable is dichotomous, taking the value 1 if respondents report having a regular family doctor and zero otherwise. Social capital is indicated by: 1) the living arrangements of the individual: living unattached alone, living with partner/ spouse only, living with partner/spouse and children, single parent living with children, or living with others, and by family status to reflect the potential for immediately available care (e.g., Folland, 2006); 2) the reported number of close relatives and friends; 3) two indices capturing individuals' feelings or the quality

of their social support: AFFECTION (from the questions: How often do you have someone who shows you love and affection? How often do you have someone who hugs you? How often do you 
have someone to love you and make you feel wanted?) Each were scored on a scale of 1-5, ranging from none of the time, a little of the time, some of the time, most of the time or all of the time. A composite score was derived and reported in the survey ranging from 0 to 12 ; and TANGIBLE (How often do you have someone to help you if you were confined to bed? How often do you have someone to take you to the doctor if you needed it? How often do you have someone to prepare your meals if you were unable to do it yourself? How often do you have someone to help you with daily chores if sick?). Again, a composite score was reported in the survey, ranging from 0 to 16. These two indices are highly correlated and are used one at a time in any given estimation.

In addition to social capital, we include a large array of explanatory variables: sex, age, immigrant status, household income, education, number of chronic conditions, self-rated health status, health risk factors (smoking, alcohol intake and physical activity), urban and rural settings, provincial and year dummy variables. The data set provides a measure of household income that is adjusted for the number of household members and provided in deciles. Table 1 defines all the variables.

The raw probabilities of having or not a regular family doctor are shown in table 2. Over the entire sample the probability of having a family doctor, reported in the first row, is 0.89 - in other words, about 11 percent of Canadians are without a regular family doctor. The next two rows report the conditional probabilities of having a family doctor as a function of having had a regular family doctor in the past. The probability that individuals who already have access to a family doctor maintain that access in the next cycle is between 0.94 (in 1998) and 0.96 (2010). In contrast, the likelihood of reporting access to a family doctor in any given cycle given that individuals reported not having access to a regular family doctor in the preceding cycle is between 0.40 and 0.50 . The raw data suggest a strong persistence in the access status to family doctor. We 
explore the extent to which this observed persistence is driven by state dependence (past access status) and unobserved heterogeneity versus other potential determinants.

Table 3 presents descriptive statistics for those observed in the base year (1998), observed in all six cycles, and for those observed in fewer than six cycles. A few clear differences emerge in the averages reported for these three samples: those observed in all six cycles are less likely to live alone, are younger, and are more likely to be female in a higher income group, with fewer chronic conditions and 'better' health behaviours (physical activity, smoking) relative to those observed in fewer than six cycles - all of which confirm expectations.

\section{Results}

Table 4 presents the results from ten regressions: the dynamic random effects model for the full sub-sample when social capital is defined as AFFECTION (column (1)) and when it is defined as TANGIBLE (columns (3)) and the corresponding marginal effects for the dynamic RE - endogenous initial conditions model in columns (2) and (4). We then focus on this latter approach and parse the sample by sex for the two definitions of social capital (columns (5) to (8)); and finally, we apply the endogenous initial conditions model to the 'young' group (under 40) and the older one (40+) only for TANGIBLE (for space reasons). In all cases an '(L)' preceding the variable name denotes its lagged value; '(I)' Reg Family Doc indicates if the individual had a regular family doctor in the initial cycle, necessary for the model of endogenous initial conditions.

Not surprisingly, table 4 reveals that the most important determinant of access to a family doctor in the current period is access to a family doctor in the previous cycle. From the dynamic random effects model reported in column (1), for instance, the estimated marginal effect from (L) Reg Family Doc is 0.293 meaning that the predicted probability of having a regular family doctor for our reference group (0.65) would be 0.293 points higher if it had a regular doctor last period. 
This effect is large, positive and statistically significant at the $1 \%$ level for all of our samples. The estimated effect of having a family doctor last period on the current situation, however, is consistently smaller in the endogenous initial conditions model suggesting that ignoring this endogeneity may result in overstating the effect of persistence (stability) in health care access.

The estimated marginal impact of previous access to a family doctor declines as we control for progressively more factors: after controlling for both observed and unobserved characteristics: taking account of both heterogeneity and the endogenous initial conditions leads to a fall in the impact of having a regular family doctor last period on having one in the current period from 0.293 to 0.177 points. This pattern persists irrespective of how we measure social capital (Affection or Tangible).

Social capital has a positive impact on the probability of having a regular family doctor, except for the female sample when we use the Tangible measure of social capital, where it has no statistical effect. The effects arising from our two measures of social capital, ceteris paribus, are quite small: for instance, from the endogenous initial conditions model in column (2), a one standard deviation increase (2.44 points) in the Affection index would increase the likelihood of having a regular family doctor by 0.0049 points; a similar increase in the Tangible index (3.19 points) leads to a 0.0055 point increase, both representing a less than $1 \%$ increase in the estimated predicted probability of having a family doctor for our reference group (calculated by dividing the point increase by the predicted probability reported at the end of the table, times 100). The impact of social capital is generally both larger in magnitude and in statistical significance for males and generally not statistically significant for females. For males, a one standard deviation increase ( 2.44 points) in the Affection index or in the Tangible index ( 3.15 points) leads to a 0.56 percent and a 0.72 percent increases in the predicted probability of having a regular family doctor. 
Overall, the effects of household living arrangements are larger than our Affectation and Tangible measures of social capital: in other words, the residual impact of 'tangible' or 'affection' is smaller than the impact of living with others on the likelihood of having a regular family doctor. Except for in the two female sub-samples reported in table 4, those who live alone are less likely to have a regular family doctor than in any other living arrangement. The likelihood that females will have a regular family doctor, however, is not dependent upon whether they live alone or with a spouse, nor does the number of relatives matter. Aside from when living with a spouse and children, the household living arrangement does not matter for women but it does for men. Men living alone are 0.027 points or $3.8 \%$ less likely to have a regular family doctor, ceteris paribus, relative to men living with others (reference group), whereas those living with a spouse only are $3.1 \%$ more likely to have a regular family doctor relative to the reference group. ${ }^{2}$ Living with a spouse clearly matters for men but not women when it comes to this aspect of their life. Finally, the number of relatives and friends has no significant impact on the likelihood of having regular family doctor in all specifications, for the full sample or the subsamples of females and males.

In order to examine whether the effect of social capital and living arrangements vary by age, we re-estimate the dynamic RE -- endogenous model on two subsamples: those with age below 40 and those 40 or older. The results are reported in table 4 (columns (9) and (10)), and show that the effect of Tangible and living arrangements are both larger in magnitude and typically statistically significant only for those younger than 40 . For instance, for individuals younger than 40, a one standard deviation change in the Tangible index (3.28 points) leads to a 0.80 percent increase in the likelihood of having a regular family doctor; the likelihood of having a regular family doctor is lowered by 3.5 percent for those living alone, whereas it is 3.2 percent and 5.6

\footnotetext{
${ }^{2}$ In all cases involving a dummy variable, when we mention a percentage change, this has been calculated by dividing the estimated marginal effect by the predicted probability (reported at the end of the table) times 100 .
} 
percent larger for those living with spouse only or living with spouse and kids, respectively. In contrast, for those aged 40 and more, a one standard deviation increase (3.35) in the Tangible index leads to a very small 0.36 percent increase in the probability of having a family doctor, and living with spouse only is associated with a 1.2 percent increase in the probability of having a family doctor. Bottom line: although younger individuals on average are less likely to have a regular family doctor, they seem to benefit more from access to social capital.

The estimated rho reported at the end of table 4 Rho is also known as the intra-class correlation coefficient, and measures the percentage of the latent variance that is attributable to unobserved heterogeneity. We see that it is always higher in the endogenous initial conditions approach, suggesting that dealing with endogenous initial conditions does, indeed, help explain more of the unobserved heterogeneity in the sample (25\% as compared to $14 \%)$.

Thus far, our results show that both social capital and living arrangements have a statistically significant effect on the likelihood of having a regular family doctor, although some of the effects are quite small in size. The mechanism by which they influence access, however, is unclear: does access to social capital increase the probability that a given individual find a regular family doctor or does it, instead, help individuals to maintain their affiliation with a regular doctor? To get more insight into the actual mechanism, we divide the sample into two subsamples: those who had no family doctor in the previous cycle (t-1), and those who did, and apply the endogenous initial conditions approach to these sub-groups.

If we focus only on the group that previously had no family doctor, we see from table 5 that the marginal effects of the Tangible index and of living arrangements are markedly higher in magnitude for those who lacked access to a family doctor in the previous period as compared to those who already had one. For instance, among those who previously had no family doctor, a 
one standard deviation change in the Tangible index (3.40 points) leads to a $3.62 \%$ increase in the likelihood of having a regular family doctor; and compared to individuals living with others, those living alone are 9.36 percent less likely to have a family doctor, while those living with spouse only or with spouse and kids are 17.5 percent and 15.8 percent more likely to have a regular family doctor. These are much larger impacts than in any of the previous specifications.

For those who previously (t-1) had a regular family doctor, a one standard deviation change in Tangible ( 3.16 points) leads to only a 0.33 percent increase in the likelihood of remain having a regular family doctor. Those living alone are 1.2 percent less likely to continue to have a regular doctor; and those living with spouse and kids are 0.95 percent more likely to remain still have a regular doctor. These results clearly indicate that social capital matters most when it comes to obtaining a regular family doctor for those individuals who lacked one in the previous cycle. This suggests that the mechanism of influence is by helping individuals find a doctor, rather than influencing the likelihood of remaining attached to a physician, which seems sensible.

\section{Conclusions}

This is the first study to examine the causal effects of social capital on the likelihood of having a regular family doctor - one factor that has important consequences for health-care access. We find robust evidence of a statistically significant and positive link between social capital and the likelihood that an individual reports having a regular family doctor.

Although sometimes the estimated coefficients are modest in magnitude, individuals with higher levels of social capital - irrespective of how defined - are more likely to have a regular family doctor. It is also clear that past access to a family doctor is an important determinant for both current and future access, and that there is considerable unobserved heterogeneity. Indeed, we estimate that unobserved heterogeneity explains about $25 \%$ of the variations in access to a 
regular family doctor, and it is significantly correlated with the access to a family doctor over the twelve years of the panel. Controlling for heterogeneity and initial conditions is thus important when trying to examine the stability in access to health care.

How should we interpret these results? The estimated marginal effects of social capital, including living arrangements, on the likelihood of having a family doctor are markedly higher for those who lacked access in the previous cycle as compared to those who already had a regular family doctor. This suggests that the mechanism by which social capital and living arrangements influence the likelihood of having a regular family doctor is by making it easier to find a doctor when one is needed. Once an individual has been accepted into a family doctor's practice, social capital is much less important for ongoing access.

Empirical analyses are inherently limited by available data, and this study is no exception. We had to rely on self-reported information on social capital, it would have been useful to have less subjective measures of social networks in order to judge the extent of any reporting bias. The NPHS ended in 2011 which is unfortunate as it was a rich source of longitudinal data; it also means that analyses based on these data will be difficult to update and replicate in the future.

The overall benefits of having a regular family doctor are numerous, including better continuity and quality of care received (Tsai et al., 2010) and improved health status (Gulliford, 2002; Gravelle et al., 2007). A key policy implication from our work is that particular attention needs to be given to strengthening pathways to accessing a regular family doctor for those living alone, particularly below the age of 40 . We show that early access leads to persistent access which bodes well for short and long term health outcomes. 


\section{References}

Arulampalam W., \& Stewart M. (2009). Simplified implementation of the Heckman estimator of the dynamic probit model and a comparison with alternative estimators. Oxford Bulletin of Economics and Statistics; 71 (5): 659-681.

Averett S., Argys L., \& Kohn J. (2014). Friends with health benefits: does individual-level social capital improve health? Eastern Economic Journal; 40 (2): 181-201.

Barefoot J., Maynard K., Beckam J., Brummett B., Hooker K., \& Siegler I. (1998). Trust, health, and longevity. Journal of Behavioral Medicine; 21:517-526.

Biewen M. (2004). Measuring state dependence in individual poverty status: are there feedback effects to employment decisions and household composition? IZA Discussion Paper 1138, Institute for the Study of Labour (IZA), Bonn. ftp://repec.iza.org/RePEc/Discussionpaper/dp1138.pdf.

Chay K., \& Hyslop D. (2000). Identification and estimation of dynamic binary response panel data models: empirical evidence using alternative approaches. working paper. http://citeseerx.ist.psu.edu/viewdoc/download?doi=10.1.1.127.947\&rep=rep1\&type=pdf.

Chamberlain G. (1984). Panel data, in: Z. Griliches \& M. D. Intriligator (ed.), Handbook of Econometrics, edition 1, volume 2, chapter 22, pages 1247-1318 Elsevier.

Clark K., \& Kanellopoulos N. (2013). Low pay persistence in Europe. Labour Economic;23: $122-134$.

Contoyannis P., Jones A., \& Rice N. (2004). The dynamics of health in the British Household Panel Survey. Journal of Applied Econometrics; 19(4): 473-503.

Deri C. (2005). Social networks and health service utilization. Journal of Health Economics; 24:1076-1107.

Devillanova C. (2008). Social networks, information and health care utilization: evidence from undocumented immigrants in Milan. Journal of Health Economics; 27:265-286.

Devlin RA., \& Rudolph-Zbarsky J. (2014). Social networks and the probability of having a regular family doctor. Social Science and Medicine; 115: 21-28.

Dunlop S., Peter C., \& McIsaac W. (2000). Socio-economic status and the utilization of physician's services: results from the Canadian National Population Health Survey. Social Science and Medicine; 51: 123-133.

Folland S. (2006). Value of life and behavior toward health risks: an interpretation of social capital. Health Economics; 15:159-71. 
Gravelle H., Morris S., \& Sutton M. (2007). Are family physicians good for you? Endogenous doctor supply and individual health. Health Research and Educational Trust; 43(4): 1128-1144.

Greene W., \& Hensher D. (2010). Modeling ordered choices. Cambridge University Press, 382 pages.

Gulliford M. (2002). Availability of primary care doctors and population health in England: is there an association? Journal of Public Health Medicine; 24(4): 252-254.

Heckman J. (1981). The incidental parameters problem and the problem of initial conditions in estimating a discrete time-discrete data stochastic process. In Structural Analysis of Discrete Data with Econometric Applications. Manski CF., McFadden D. (eds). MIT Press, Cambridge, MA.

Kohn J., \& Liu J. (2013). The dynamics of medical care use in the British household panel survey. Health Economics; 22(6): 687-710.

Lambrew J., DeFriese G., Carey T., Ricketts T., \& Biddle A. (1996). The effects of having a regular doctor on access to primary care. Medical Care; 34 (2): 138-151.

Laporte A., Nauenberg E., \& Shen L. (2008). Aging, social capital, and health care utilization in Canada. Health Economics, Policy, Law; 3: 393-411.

McIssac W., Fuller-Thomson E., \& Talbot Y. (2001). Does having regular care by a family physician improve preventive care? Canada Family Physician; 47: 70-76.

Miltiades B., \& Wu B. (2008). Factors affecting physician visits in Chinese and Chinese immigrant samples. Social Science and Medicine; 66:704-714.

Morales M., Caminal J., Starfield B., Sánchez E., \& Casanova C. (2004). The role of primary care in preventing ambulatory care sensitive conditions. European Journal of Public Health; 14(3):1-6.

Mundlak Y. (1978). On the pooling of time Series and Cross Section data. Econometrica; 46(1): 69-85.

Nickell S. (1981). Biases in dynamic models with Fixed effects. Econometrica: 1417-26.

Orr S., Charney E., Straus J., \& Bloom B. (1991). Emergency room use by low income children with a regular source of health care. Medical Care; 29(3): 283-286.

Putnam RD. (2000). Bowling alone. New York: Simon and Schuster.

Rose R. (2000). How much does social capital add to individual health? A survey study of Russians. Social Science and Medicine; 51:1421-35.

Samek D., Laporte A., Nauenberg E., Shen L., \& Coyte P. (2012). The effect of social capital on the use of general practitioners: A comparison of immigrants and non-immigrants in Ontario. Health Care Policy; 8(1): 50-66. 
Sanmartin C., Gendron F., Berthelot J., \& Murphy K. (2004). Access to Health Care Services in Canada. Statistics Canada Catalogue no. 82-575-XIE.

Sanmartin C., \& Ross N. (2006). Experiencing difficulties accessing first-contact health services in Canada: Canadians without regular doctors and recent immigrants have difficulties accessing first-contact healthcare services. Health Policy; 1:103-119.

Statistics Canada (2014). Access to a regular medical doctor.

https://www.statcan.gc.ca/pub/82-625-x/2015001/article/14177-eng.htm

Statistics Canada National Population Health Survey Household Component (2009) [http://www.statcan.gc.ca/imdb-bmdi/document/ 3225_D10_T9_V3-eng.pdf].

Stewart M. (2007). The interrelated dynamics of unemployment and low pay. Journal of Applied Econometrics; 22: 511-531.

Tsai J, Shi L., Yu W-L., \& Lebrun L. (2010). Usual source of care and the quality of medical care experiences: Across sectional survey of patients from Taiwanese community. Medical Care; 48 (7):1-7.

Veenstra G. (2000). Social capital, SES and health: an individual-level analysis. Social Science and Medicine; 50:619-629.

Wooldridge J. (2005). Simple solutions to the initial conditions problem in dynamic, nonlinear panel data models with unobserved heterogeneity. Journal of Applied Econometrics; 20: $39-54$. 


\section{Table 1: Variable definitions}

\begin{tabular}{|c|c|}
\hline Reg Family Doc. & $1=$ has regular medical doc, $0=$ otherwise \\
\hline (L) Reg Family Doc. & $1=$ had regular medical doc in the previous cycle, $0=$ otherwise \\
\hline (I) Reg Family Doc. & $1=$ had regular medical doc in the initial cycle, $0=$ otherwise \\
\hline Male & $1=$ male, $0=$ female \\
\hline Age & age in completed years \\
\hline AgeSq & age squared \\
\hline $\begin{array}{l}\text { (L) Living Arrangement } \\
\text { (L) Alone }\end{array}$ & $\begin{array}{l}\text { (L) indicates the living arrangement status in the previous cycle. } \\
1=\text { living alone, } 0=\text { otherwise }\end{array}$ \\
\hline (L) WSpouse only & $1=$ living with spouse or partner, $0=$ otherwise \\
\hline (L) WSpouse and kid(s) & $1=$ living with spouse or partner and kid (s), $0=$ otherwise \\
\hline (L) Single parent and kid(s) & $1=$ single parent and kid $(\mathrm{s}), 0=$ otherwise \\
\hline (L) Living w others & $1=$ living with others, $0=$ otherwise \\
\hline (L) Social capital & (L) indicate the level of social capital in the previous cycle \\
\hline (L) Affection & affection index: $0-12$ \\
\hline (L) Tangible & tangible index :0-16 \\
\hline (L) Num RF & Number of relatives and close friends: 0-99. \\
\hline Less than Sec & $1=$ less than secondary, $0=$ otherwise. Reference \\
\hline Sec grad & $1=$ secondary school diploma, $0=$ otherwise \\
\hline Some Post Sec & $1=$ some post - secondary diploma, $0=$ otherwise \\
\hline Post-Sec & $1=$ post-secondary diploma, $0=$ otherwise \\
\hline Income Adequacy & $\begin{array}{l}\text { four income ratio dummy variables representing total household income in } \\
\text { relation to the number of household members. For more details see: Statistics } \\
\text { Canada National Population Health Survey Household Component. } 2009 \\
\text { [http://www.statcan.gc.ca/imdb-bmdi/document/3225_D10_T9_V3-eng.pdf]. }\end{array}$ \\
\hline Low Income & $1=$ household income is in low income group, $0=$ otherwise \\
\hline Low Middle Income & $1=$ household income is in middle low income group, $0=$ otherwise \\
\hline High Middle Income & $1=$ household income in high middle income group, $0=$ otherwise \\
\hline High Income & $1=$ household income in high income group, $0=$ otherwise \\
\hline $\operatorname{Imm}<10$ & $1=$ immigrant and years since immigration is less than 10 years. \\
\hline $\operatorname{Imm}>=10$ & $1=$ immigrant and years since immigration is equal or greater than 10 years. \\
\hline Chronic Conditions & $\begin{array}{l}\text { Individual is asked whether he/she has a long-term health conditions that only } \\
\text { have been diagnosed by health professional., such as, Asthma, Arthritis, High } \\
\text { blood pressure, Diabetes, Heart disease, Cancer, effects of Stroke, Cataracts } \\
\text { and Alzheimer's disease or dementia }\end{array}$ \\
\hline NumConds- 0 & $1=$ no chronic condition. Reference \\
\hline NumConds- 1 & $1=$ only one chronic condition \\
\hline NumConds- 2 or 3 & $1=$ two or three chronic conditions \\
\hline NumConds- 4+ & $1=$ four or more chronic conditions \\
\hline HFP & $1=$ health status is fair or poor, $0=$ Otherwise \\
\hline HG & $1=$ health status is good, $0=$ Otherwise \\
\hline HVG & $1=$ health status is very good, $0=$ Otherwise \\
\hline HEX & $1=$ if health status is excellent, $0=$ Otherwise: Reference \\
\hline DrinkNever & $1=$ never drinks alcohol, $0=$ otherwise \\
\hline DrinkReg & $\begin{array}{l}1=\text { drinks regularly, } 0=\text { otherwise. Regular drinking means the consumption } \\
\text { of at least one alcoholic beverage per month in the last } 12 \text { months. }\end{array}$ \\
\hline DrinkOcc & $\begin{array}{l}1=\text { drinks occasionally, } 0=\text { otherwise. Occasional drinking means the } \\
\text { consumption of an alcoholic beverage less than once per month (consume less } \\
\text { than a bottle) in the last } 12 \text { months. }\end{array}$ \\
\hline DrinkForm & $\begin{array}{l}1=\text { drinks formerly, where former drinkers are those who have previously } \\
\text { consumed alcohol but did not do so in the previous twelve months, } 0= \\
\text { otherwise. }\end{array}$ \\
\hline SmokeNever & $1=$ never smokes, $0=$ otherwise: Reference \\
\hline SmokeDaily & $1=$ smokes daily, $0=$ otherwise \\
\hline
\end{tabular}




\begin{tabular}{|ll|}
\hline SmokeOcc & $1=$ smokes occasionally, $0=$ otherwise \\
Physically Active & $1=$ physically active, $0=$ otherwise. Reference \\
Physically Mod & $1=$ moderately active, $0=$ otherwise \\
Physically InActive & $1=$ physically inactive, $0=$ otherwise \\
Urban & $1=$ living in urban area; $0=$ rural area \\
NFLD & $1=$ Newfoundland, $0=$ otherwise \\
PEI & $1=$ Prince Edward, $0=$ otherwise \\
NS & $1=$ Nova Scotia, $0=$ otherwise \\
NB & $1=$ New Brunswick, $0=$ otherwise \\
QC & $1=$ Quebec, $0=$ otherwise \\
MAN & $1=$ Manitoba, $0=$ otherwise \\
SAS & $1=$ Saskatchewan, $0=$ otherwise \\
ALB & $1=$ Alberta, $0=$ otherwise \\
BC & $1=$ British Columbia, $0=$ otherwise \\
ON & $1=$ Ontario, $0=$ otherwise: Reference \\
Year: $1998 / 99$ & $1=$ surveyed in $1998 / 1999,0$ otherwise \\
Year: $2000 / 01$ & $1=$ surveyed in $2000 / 2001,0$ otherwise \\
Year: $2002 / 03$ & $1=$ surveyed in $2002 / 2003,0$ otherwise \\
Year: $2004 / 05$ & $1=$ surveyed in $2004 / 2005,0$ otherwise \\
Year: $2006 / 07$ & $1=$ surveyed in $2006 / 2007,0$ otherwise \\
Year: $2008 / 09$ & $1=$ surveyed in $2008 / 2009,0$ otherwise \\
Year: $2010 / 11$ & $1=$ surveyed in $2010 / 2011,0$ otherwise \\
\hline
\end{tabular}




\begin{tabular}{|c|c|c|c|c|c|c|c|c|}
\hline \multicolumn{9}{|c|}{ 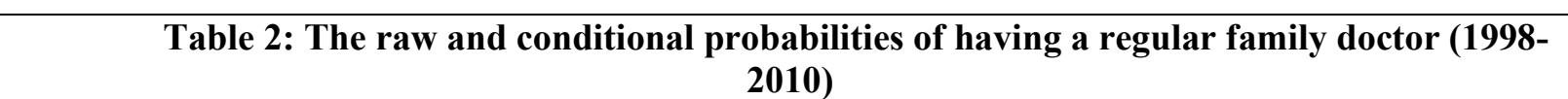 } \\
\hline & $1998 / 99$ & $2000 / 01$ & $2002 / 03$ & $2004 / 05$ & $2006 / 07$ & $2008 / 09$ & $2010 / 11$ & Total \\
\hline $\operatorname{Pr}\left(\right.$ FDoc $\left._{t}=1\right)$ & 0.87 & 0.88 & 0.89 & 0.88 & 0.90 & 0.90 & 0.87 & 0.89 \\
\hline $\begin{array}{l}\operatorname{Pr}\left(F_{D o c}=\right. \\
\left.1 \mid F D o c_{t-1}=1\right)\end{array}$ & & 0.94 & 0.94 & 0.94 & 0.95 & 0.95 & 0.96 & 0.95 \\
\hline $\begin{array}{l}\operatorname{Pr}\left(F_{D o c}=\right. \\
\left.1 \mid F \operatorname{Doc}_{t-1}=0\right)\end{array}$ & & 0.50 & 0.48 & 0.45 & 0.48 & 0.42 & 0.40 & 0.47 \\
\hline
\end{tabular}




\begin{tabular}{|c|c|c|c|}
\hline Variable & $\begin{array}{l}\text { Base } \\
\text { Year }\end{array}$ & $\begin{array}{l}\text { Observed } \\
\text { in all } 6 \\
\text { cycles }\end{array}$ & $\begin{array}{l}\text { Obs. } \\
\text { Fewer } \\
\text { than } 6 \\
\text { cycles }\end{array}$ \\
\hline & $\begin{array}{l}\text { mean } \\
\text { (S.D.) }\end{array}$ & $\begin{array}{l}\text { mean } \\
\text { (S.D.) }\end{array}$ & $\begin{array}{l}\text { mean } \\
\text { (S.D.) }\end{array}$ \\
\hline Reg Family Doc. & 0.867 & 0.861 & 0.870 \\
\hline Alone & 0.162 & 0.114 & 0.185 \\
\hline WSpouse only & 0.246 & 0.216 & 0.261 \\
\hline WSpouse and Kid(s) & 0.327 & 0.423 & 0.282 \\
\hline SnglParent and Kids(s) & 0.049 & 0.041 & 0.053 \\
\hline Affection & $\begin{array}{l}10.437 \\
(2.413)\end{array}$ & $\begin{array}{l}10.725 \\
(2.042)\end{array}$ & $\begin{array}{l}10.291 \\
(2.560)\end{array}$ \\
\hline Tangible & $\begin{array}{l}13.435 \\
(3.385)\end{array}$ & $\begin{array}{l}13.664 \\
(3.057)\end{array}$ & $\begin{array}{l}13.325 \\
(3.525)\end{array}$ \\
\hline Num Relatives & $\begin{array}{c}6.482 \\
(6.290)\end{array}$ & $\begin{array}{c}6.625 \\
(5.714)\end{array}$ & $\begin{array}{r}6.414 \\
(6.547)\end{array}$ \\
\hline Age (years) & $\begin{array}{c}44.97 \\
(16.86)\end{array}$ & $\begin{array}{c}41.02 \\
(12.36)\end{array}$ & $\begin{array}{r}46.85 \\
(18.33)\end{array}$ \\
\hline Male & 0.482 & 0.466 & 0.490 \\
\hline Low Income & 0.119 & 0.060 & 0.148 \\
\hline Low Middle Income & 0.258 & 0.203 & 0.284 \\
\hline High Middle Income & 0.383 & 0.411 & 0.369 \\
\hline High Income & 0.240 & 0.326 & 0.199 \\
\hline $\operatorname{Imm}<10$ & 0.027 & 0.016 & 0.032 \\
\hline $\operatorname{Imm} \geq 10$ & 0.149 & 0.124 & 0.161 \\
\hline Num Conds- 0 & 0.372 & 0.394 & 0.361 \\
\hline Num Conds- 1 & 0.268 & 0.287 & 0.259 \\
\hline Num Conds- 2 or 3 & 0.257 & 0.244 & 0.264 \\
\hline Num Conds- 4+ & 0.103 & 0.0755 & 0.116 \\
\hline Activity- limit & 0.123 & 0.069 & 0.150 \\
\hline Poor Health & 0.093 & 0.042 & 0.117 \\
\hline Good Health & 0.265 & 0.222 & 0.285 \\
\hline V Good Health & 0.402 & 0.451 & 0.378 \\
\hline Excel Health & 0.240 & 0.285 & 0.220 \\
\hline Drink Reg & 0.613 & 0.690 & 0.575 \\
\hline Drink Occ & 0.204 & 0.188 & 0.212 \\
\hline Drink Former & 0.120 & 0.088 & 0.136 \\
\hline Drink Never & 0.063 & 0.034 & 0.077 \\
\hline Physically Inactive & 0.537 & 0.505 & 0.552 \\
\hline Physically Mod & 0.253 & 0.271 & 0.244 \\
\hline Physically Active & 0.210 & 0.224 & 0.204 \\
\hline Smoke Daily & 0.245 & 0.211 & 0.261 \\
\hline Smoke Occ & 0.037 & 0.035 & 0.039 \\
\hline Smoke Never & 0.718 & 0.754 & 0.700 \\
\hline Urban & 0.878 & 0.873 & 0.880 \\
\hline Observations & 10,403 & 3,356 & $\mathbf{7 , 0 4 7}$ \\
\hline
\end{tabular}




\begin{tabular}{|c|c|c|c|c|c|c|c|c|c|c|}
\hline \multirow[t]{3}{*}{ Variables } & \multicolumn{2}{|c|}{ Affection } & \multicolumn{2}{|c|}{ Tangible } & \multicolumn{2}{|c|}{ Affection } & \multicolumn{2}{|c|}{ Tangible } & \multicolumn{2}{|c|}{ Tangible } \\
\hline & \multicolumn{2}{|c|}{ All persons } & \multicolumn{2}{|c|}{ All persons } & \multicolumn{2}{|c|}{$\begin{array}{c}\text { Dynamic RE-Endog - } \\
\text { By gender }\end{array}$} & \multicolumn{2}{|c|}{$\begin{array}{c}\text { Dynamic RE-Endog - By } \\
\text { gender }\end{array}$} & \multicolumn{2}{|c|}{$\begin{array}{c}\text { Dynamic RE-Endog - By } \\
\text { Age }\end{array}$} \\
\hline & $\begin{array}{l}\text { Dynamic } \\
\text { RE probit }\end{array}$ & $\begin{array}{l}\text { Dynamic } \\
\text { RE-Endog }\end{array}$ & $\begin{array}{l}\text { Dynamic } \\
\text { RE probit }\end{array}$ & $\begin{array}{c}\text { Dynamic } \\
\text { RE-Endog }\end{array}$ & Females & Males & Females & Males & Age $<40$ & Age $>=40$ \\
\hline (L) Reg Family Doc & $\begin{array}{l}0.293 * * * \\
(0.014)\end{array}$ & $\begin{array}{l}0.177 * * * \\
(0.012)\end{array}$ & $\begin{array}{l}0.292^{* * *} \\
(0.014)\end{array}$ & $\begin{array}{l}0.176^{* * *} \\
(0.012)\end{array}$ & $\begin{array}{l}0.145^{* * *} \\
(0.017)\end{array}$ & $\begin{array}{l}0.211 * * * \\
(0.017)\end{array}$ & $\begin{array}{l}0.145^{* * *} \\
(0.017)\end{array}$ & $\begin{array}{l}0.209 * * * \\
(0.017)\end{array}$ & $\begin{array}{l}0.218 * * * \\
(0.021)\end{array}$ & $\begin{array}{l}0.195^{* * *} \\
(0.018)\end{array}$ \\
\hline (I) Reg Family Doc & & $\begin{array}{l}0.065 * * * \\
(0.004)\end{array}$ & & $\begin{array}{l}0.065 * * * \\
(0.004)\end{array}$ & $\begin{array}{l}0.056^{* * *} \\
(0.005)\end{array}$ & $\begin{array}{l}0.078 * * * \\
(0.007)\end{array}$ & $\begin{array}{l}0.057 * * * \\
(0.005)\end{array}$ & $\begin{array}{l}0.079 * * * \\
(0.007)\end{array}$ & $\begin{array}{l}0.091 * * * \\
(0.010)\end{array}$ & $\begin{array}{l}0.053 * * * \\
(0.004)\end{array}$ \\
\hline (L) Social capital & $\begin{array}{l}0.002 * * * \\
(0.001)\end{array}$ & $\begin{array}{l}0.002 * * * \\
(0.001)\end{array}$ & $\begin{array}{l}0.001 * * * \\
(0.000)\end{array}$ & $\begin{array}{l}0.001 * * * \\
(0.000)\end{array}$ & $\begin{array}{l}0.001 * \\
(0.001)\end{array}$ & $\begin{array}{l}0.002^{* *} \\
(0.001)\end{array}$ & $\begin{array}{l}2.3 \mathrm{E}-04 \\
(0.001)\end{array}$ & $\begin{array}{l}0.002 * * * \\
(0.001)\end{array}$ & $\begin{array}{l}0.002 * * \\
(0.001)\end{array}$ & $\begin{array}{l}0.001 * * \\
(0.000)\end{array}$ \\
\hline (L) Alone & $\begin{array}{l}-0.018 * * * \\
(0.004)\end{array}$ & $\begin{array}{l}-0.015^{* * *} \\
(0.004)\end{array}$ & $\begin{array}{l}-0.018 * * * \\
(0.004)\end{array}$ & $\begin{array}{l}-0.015^{* * *} \\
(0.004)\end{array}$ & $\begin{array}{l}-0.004 \\
(0.005)\end{array}$ & $\begin{array}{l}-0.027 * * * \\
(0.007)\end{array}$ & $\begin{array}{l}-0.005 \\
(0.005)\end{array}$ & $\begin{array}{l}-0.026 * * * \\
(0.007)\end{array}$ & $\begin{array}{l}-0.028 * * * \\
(0.010)\end{array}$ & $\begin{array}{l}-0.003 \\
(0.004)\end{array}$ \\
\hline (L) WSpouse only & $\begin{array}{l}0.011 * * * \\
(0.004)\end{array}$ & $\begin{array}{l}0.010^{* *} \\
(0.004)\end{array}$ & $\begin{array}{l}0.012 * * * \\
(0.004)\end{array}$ & $\begin{array}{l}0.011^{* * *} \\
(0.004)\end{array}$ & $\begin{array}{l}0.002 \\
(0.005)\end{array}$ & $\begin{array}{l}0.022 * * * \\
(0.007)\end{array}$ & $\begin{array}{l}0.003 \\
(0.005)\end{array}$ & $\begin{array}{l}0.022 * * * \\
(0.007)\end{array}$ & $\begin{array}{l}0.029 * * * \\
(0.010)\end{array}$ & $\begin{array}{l}0.011 * * \\
(0.004)\end{array}$ \\
\hline (L) WSpouse and Kid(s) & $\begin{array}{l}0.016 * * * \\
(0.004)\end{array}$ & $\begin{array}{l}0.014 * * * \\
(0.004)\end{array}$ & $\begin{array}{l}0.017 * * * \\
(0.004)\end{array}$ & $\begin{array}{l}0.015 * * * \\
(0.004)\end{array}$ & $\begin{array}{l}0.012 * * * \\
(0.005)\end{array}$ & $\begin{array}{l}0.017 * * \\
(0.007)\end{array}$ & $\begin{array}{l}0.013 * * * \\
(0.004)\end{array}$ & $\begin{array}{l}0.017 * * \\
(0.007)\end{array}$ & $\begin{array}{l}0.046 * * * \\
(0.008)\end{array}$ & $\begin{array}{l}0.001 \\
(0.004)\end{array}$ \\
\hline (L) SnglParent and Kid(s) & $\begin{array}{l}0.006 \\
(0.006)\end{array}$ & $\begin{array}{l}0.008 \\
(0.006)\end{array}$ & $\begin{array}{l}0.007 \\
(0.006)\end{array}$ & $\begin{array}{l}0.008 \\
(0.006)\end{array}$ & $\begin{array}{l}0.006 \\
(0.006)\end{array}$ & $\begin{array}{l}0.011 \\
(0.016)\end{array}$ & $\begin{array}{l}0.006 \\
(0.006)\end{array}$ & $\begin{array}{l}0.011 \\
(0.016)\end{array}$ & $\begin{array}{l}0.018 \\
(0.016)\end{array}$ & $\begin{array}{l}0.002 \\
(0.006)\end{array}$ \\
\hline (L) Num Relatives & $\begin{array}{l}3.1 \mathrm{E}-04 \\
(2.1 \mathrm{E}-04)\end{array}$ & $\begin{array}{l}1.9 \mathrm{E}-04 \\
(0.0 \mathrm{E}-04)\end{array}$ & $\begin{array}{l}3.3 \mathrm{E}-04 \\
(2.1 \mathrm{E}-04)\end{array}$ & $\begin{array}{l}2.0 \mathrm{E}-04 \\
(2.0 \mathrm{E}-04)\end{array}$ & $\begin{array}{l}-9.8 \mathrm{E}-05 \\
(2.5 \mathrm{E}-04)\end{array}$ & $\begin{array}{l}3.9 \text { E-04 } \\
(3.4 \text { E-04) }\end{array}$ & $\begin{array}{l}-5.6 \mathrm{E}-05 \\
(2.5 \mathrm{e}-04)\end{array}$ & $\begin{array}{l}3.9 \text { E-04 } \\
(3.4 \text { E-04) }\end{array}$ & $\begin{array}{l}0.001 \\
(0.001)\end{array}$ & $\begin{array}{l}1.6 \mathrm{E}-04 \\
(1.9 \mathrm{E}-04)\end{array}$ \\
\hline Mean (Sec) & & $\begin{array}{l}0.023 * * \\
(0.011)\end{array}$ & & $\begin{array}{l}0.023 * * \\
(0.011)\end{array}$ & $\begin{array}{l}0.005 \\
(0.012)\end{array}$ & $\begin{array}{l}0.051 * * * \\
(0.019)\end{array}$ & $\begin{array}{l}0.005 \\
(0.012)\end{array}$ & $\begin{array}{l}0.052^{* * *} \\
(0.019)\end{array}$ & $\begin{array}{l}0.030 \\
(0.035)\end{array}$ & $\begin{array}{l}0.010 \\
(0.009)\end{array}$ \\
\hline Mean (Some Post) & & $\begin{array}{l}0.004 \\
(0.010)\end{array}$ & & $\begin{array}{l}0.004 \\
(0.010)\end{array}$ & $\begin{array}{l}-0.012 \\
(0.011)\end{array}$ & $\begin{array}{l}0.026 \\
(0.018)\end{array}$ & $\begin{array}{l}-0.012 \\
(0.011)\end{array}$ & $\begin{array}{l}0.027 \\
(0.018)\end{array}$ & $\begin{array}{l}0.007 \\
(0.032)\end{array}$ & $\begin{array}{l}-0.008 \\
(0.009)\end{array}$ \\
\hline Mean (Post Sec) & & $\begin{array}{l}0.014 \\
(0.009)\end{array}$ & & $\begin{array}{l}0.014 \\
(0.009)\end{array}$ & $\begin{array}{l}-0.006 \\
(0.011)\end{array}$ & $\begin{array}{l}0.041 * * \\
(0.017)\end{array}$ & $\begin{array}{l}-0.006 \\
(0.011)\end{array}$ & $\begin{array}{l}0.043 * * \\
(0.017)\end{array}$ & $\begin{array}{l}0.007 \\
(0.031)\end{array}$ & $\begin{array}{l}0.006 \\
(0.009)\end{array}$ \\
\hline Mean (Low Income) & & $\begin{array}{l}-0.027 * * \\
(0.012)\end{array}$ & & $\begin{array}{l}-0.027 * * \\
(0.012)\end{array}$ & $\begin{array}{l}-0.033 * * * \\
(0.012)\end{array}$ & $\begin{array}{l}-0.004 \\
(0.024)\end{array}$ & $\begin{array}{l}-0.034 * * * \\
(0.012)\end{array}$ & $\begin{array}{l}-0.003 \\
(0.024)\end{array}$ & $\begin{array}{l}-0.047 \\
(0.030)\end{array}$ & $\begin{array}{l}-0.025^{* *} \\
(0.012)\end{array}$ \\
\hline Mean (Low Middle Income) & & $\begin{array}{l}-0.017 * * \\
(0.008)\end{array}$ & & $\begin{array}{l}-0.017 * * \\
(0.008)\end{array}$ & $\begin{array}{l}-0.005 \\
(0.009)\end{array}$ & $\begin{array}{l}-0.043 * * * \\
(0.016)\end{array}$ & $\begin{array}{l}-0.005 \\
(0.009)\end{array}$ & $\begin{array}{l}-0.043 * * * \\
(0.016)\end{array}$ & $\begin{array}{l}-0.004 \\
(0.022)\end{array}$ & $\begin{array}{l}-0.019 * * \\
(0.008)\end{array}$ \\
\hline Mean (High Middle Income) & & $\begin{array}{l}0.002 \\
(0.007)\end{array}$ & & $\begin{array}{l}0.002 \\
(0.007)\end{array}$ & $\begin{array}{l}0.005 \\
(0.008)\end{array}$ & $\begin{array}{l}-0.001 \\
(0.012)\end{array}$ & $\begin{array}{l}0.005 \\
(0.008)\end{array}$ & $\begin{array}{l}-0.001 \\
(0.012)\end{array}$ & $\begin{array}{l}0.020 \\
(0.017)\end{array}$ & $\begin{array}{l}-0.005 \\
(0.007)\end{array}$ \\
\hline Mean (Num Conds- 1) & & $\begin{array}{l}0.012 * \\
(0.007)\end{array}$ & & $\begin{array}{l}0.012^{*} \\
(0.007)\end{array}$ & $\begin{array}{l}0.013 \\
(0.008)\end{array}$ & $\begin{array}{l}0.011 \\
(0.012)\end{array}$ & $\begin{array}{l}0.013 \\
(0.008)\end{array}$ & $\begin{array}{l}0.011 \\
(0.012)\end{array}$ & $\begin{array}{l}0.023 \\
(0.017)\end{array}$ & $\begin{array}{l}0.012 \\
(0.007)\end{array}$ \\
\hline Mean (Num Conds- 2 or 3 ) & & $\begin{array}{l}0.014^{*} \\
(0.007)\end{array}$ & & $\begin{array}{l}0.014^{*} \\
(0.007)\end{array}$ & $\begin{array}{l}0.021 * * \\
(0.008)\end{array}$ & $\begin{array}{l}0.006 \\
(0.014)\end{array}$ & $\begin{array}{l}0.021 * * \\
(0.008)\end{array}$ & $\begin{array}{l}0.006 \\
(0.014)\end{array}$ & $\begin{array}{l}0.010 \\
(0.019)\end{array}$ & $\begin{array}{l}0.019 * * * \\
(0.007)\end{array}$ \\
\hline
\end{tabular}




\begin{tabular}{|c|c|c|c|c|c|c|c|c|c|c|}
\hline \multicolumn{2}{|l|}{ Mean (Num Conds- 4+) } & $\begin{array}{l}0.019 * \\
(0.011)\end{array}$ & & $\begin{array}{l}0.019^{*} \\
(0.011)\end{array}$ & $\begin{array}{l}0.023 * * \\
(0.011)\end{array}$ & $\begin{array}{l}0.021 \\
(0.022)\end{array}$ & $\begin{array}{l}0.024 * * \\
(0.011)\end{array}$ & $\begin{array}{l}0.020 \\
(0.022)\end{array}$ & $\begin{array}{l}0.041 \\
(0.032)\end{array}$ & $\begin{array}{l}0.020^{*} \\
(0.010)\end{array}$ \\
\hline \multirow{2}{*}{\multicolumn{2}{|c|}{ Mean(HFP) }} & 0.011 & & 0.010 & $0.028 * *$ & -0.019 & $0.026^{* *}$ & -0.019 & $0.077^{*} *$ & -0.005 \\
\hline & & $(0.012)$ & & $(0.012)$ & $(0.013)$ & $(0.022)$ & $(0.013)$ & $(0.022)$ & $(0.038)$ & $(0.011)$ \\
\hline \multirow{2}{*}{\multicolumn{2}{|c|}{$\operatorname{Mean}(\mathrm{HG})$}} & 0.007 & & 0.007 & 0.014 & -0.005 & 0.013 & -0.004 & 0.025 & -0.003 \\
\hline & & $(0.008)$ & & $(0.008)$ & $(0.009)$ & $(0.015)$ & $(0.009)$ & $(0.014)$ & $(0.020)$ & $(0.008)$ \\
\hline \multirow{2}{*}{\multicolumn{2}{|c|}{ Mean (HVG) }} & 0.010 & & 0.010 & $0.016^{* *}$ & -0.002 & $0.016^{*}$ & -0.001 & 0.027 & 0.003 \\
\hline & & $(0.007)$ & & $(0.007)$ & $(0.008)$ & $(0.013)$ & $(0.008)$ & $(0.013)$ & $(0.018)$ & $(0.007)$ \\
\hline \multirow{2}{*}{\multicolumn{2}{|c|}{ Mean (Drink Reg) }} & 0.012 & & 0.012 & 0.003 & 0.023 & 0.003 & 0.022 & -0.011 & 0.006 \\
\hline & & $(0.014)$ & & $(0.014)$ & $(0.014)$ & $(0.030)$ & $(0.014)$ & $(0.030)$ & $(0.040)$ & $(0.013)$ \\
\hline \multirow{2}{*}{\multicolumn{2}{|c|}{ Mean (Drink Occ) }} & 0.008 & & 0.008 & -0.001 & 0.026 & -0.001 & 0.025 & -0.006 & 0.001 \\
\hline & & $(0.014)$ & & $(0.014)$ & $(0.014)$ & $(0.031)$ & $(0.014)$ & $(0.031)$ & $(0.041)$ & $(0.013)$ \\
\hline \multirow{2}{*}{\multicolumn{2}{|c|}{ Mean (Drink Former) }} & -0.001 & & -0.001 & 0.002 & -0.010 & 0.003 & -0.012 & -0.016 & -0.000 \\
\hline & & $(0.015)$ & & $(0.015)$ & $(0.015)$ & $(0.032)$ & $(0.015)$ & $(0.032)$ & $(0.046)$ & $(0.013)$ \\
\hline \multirow{2}{*}{\multicolumn{2}{|c|}{ Mean (PhysicallyMod) }} & $0.015^{*}$ & & $0.015^{*}$ & -0.003 & $0.040 * * *$ & -0.003 & $0.040 * * *$ & -0.010 & $0.024 * * *$ \\
\hline & & $(0.008)$ & & $(0.008)$ & $(0.010)$ & $(0.015)$ & $(0.010)$ & $(0.015)$ & $(0.021)$ & $(0.008)$ \\
\hline \multirow{2}{*}{\multicolumn{2}{|c|}{ Mean (Physically Inactive) }} & 0.002 & & 0.002 & $-0.013 *$ & $0.024 * *$ & $-0.014^{*}$ & $0.024 * *$ & -0.018 & 0.010 \\
\hline & & $(0.007)$ & & $(0.007)$ & $(0.008)$ & $(0.012)$ & $(0.008)$ & $(0.012)$ & $(0.017)$ & $(0.007)$ \\
\hline \multirow{2}{*}{\multicolumn{2}{|c|}{ Mean (SmokeDaily) }} & -0.010 & & -0.010 & -0.014 & -0.006 & -0.014 & -0.006 & 0.002 & $-0.021 * * *$ \\
\hline & & $(0.007)$ & & $(0.007)$ & $(0.008)$ & $(0.013)$ & $(0.008)$ & $(0.013)$ & $(0.018)$ & $(0.008)$ \\
\hline \multirow{2}{*}{\multicolumn{2}{|c|}{ Mean (SmokeOcc) }} & -0.003 & & -0.003 & -0.018 & 0.017 & -0.018 & 0.019 & 0.009 & -0.016 \\
\hline & & $(0.013)$ & & $(0.013)$ & $(0.015)$ & $(0.025)$ & $(0.015)$ & $(0.025)$ & $(0.028)$ & $(0.015)$ \\
\hline Rho & 0.14 & 0.25 & 0.14 & 0.25 & 0.20 & 0.30 & 0.20 & 0.30 & 0.25 & 0.22 \\
\hline The predicted probability & 0.65 & 0.77 & 0.65 & 0.77 & 0.81 & 0.71 & 0.81 & 0.71 & 0.68 & 0.76 \\
\hline $\mathrm{N}$ & 41,022 & 41,022 & 41,022 & 41,022 & 23,143 & 17,879 & 23,143 & 17,879 & 11,420 & 29,602 \\
\hline $\begin{array}{l}\text { The marginal effect of } \\
\text { Affection for each one SD } \\
\text { increase in SC }\end{array}$ & $0.75 \%$ & $0.63 \%$ & & & $0.27 \%$ & $0.69 \%$ & & & & \\
\hline $\begin{array}{l}\text { The marginal effect of } \\
\text { Tangible for each one SD } \\
\text { increase in SC }\end{array}$ & & & $0.49 \%$ & $0.41 \%$ & & & NS & $0.89 \%$ & $0.97 \%$ & $0.44 \%$ \\
\hline
\end{tabular}




\begin{tabular}{|c|c|c|c|c|}
\hline \multirow[b]{2}{*}{ Variables } & \multicolumn{2}{|c|}{ Tangible } & \multicolumn{2}{|c|}{ Affection } \\
\hline & $\begin{array}{l}\text { Previously had } \\
\text { no family doctor }\end{array}$ & $\begin{array}{l}\text { Previously had } \\
\text { family doctor }\end{array}$ & $\begin{array}{l}\text { Previously had } \\
\text { no family } \\
\text { doctor }\end{array}$ & $\begin{array}{l}\text { Previously had } \\
\text { family doctor }\end{array}$ \\
\hline (L) Social Capital & $\begin{array}{l}0.005^{*} \\
(0.003)\end{array}$ & $\begin{array}{l}0.001 * * \\
(0.000)\end{array}$ & $\begin{array}{l}0.008^{*} \\
(0.004)\end{array}$ & $\begin{array}{c}0.001^{* * * *} \\
(0.000)\end{array}$ \\
\hline (L) Alone & $\begin{array}{l}-0.044^{*} \\
(0.027)\end{array}$ & $\begin{array}{c}-0.012 * * * \\
(0.003)\end{array}$ & $\begin{array}{l}-0.043 \\
(0.027)\end{array}$ & $\begin{array}{l}-0.012 * * * \\
(0.003)\end{array}$ \\
\hline (L) WSpouse only & $\begin{array}{c}0.082 * * * \\
(0.026)\end{array}$ & $\begin{array}{c}0.005 \\
(0.003)\end{array}$ & $\begin{array}{c}0.080 * * * \\
(0.026)\end{array}$ & $\begin{array}{c}0.004 \\
(0.003)\end{array}$ \\
\hline (L) WSpouse and Kid(s) & $\begin{array}{c}0.074 * * * \\
(0.026)\end{array}$ & $\begin{array}{c}0.009 * * * \\
(0.003)\end{array}$ & $\begin{array}{c}0.071^{* * *} \\
(0.026)\end{array}$ & $\begin{array}{c}0.009^{* * *} \\
(0.003)\end{array}$ \\
\hline (L) SnglParent and Kid(s) & $\begin{array}{l}-0.027 \\
(0.046)\end{array}$ & $\begin{array}{c}0.006 \\
(0.005)\end{array}$ & $\begin{array}{l}-0.027 \\
(0.046)\end{array}$ & $\begin{array}{c}0.006 \\
(0.005)\end{array}$ \\
\hline (L) Num RF & $\begin{array}{l}-0.002 \\
(0.001)\end{array}$ & $\begin{array}{l}3.45 \mathrm{e}-05^{* *} \\
(1.7 \mathrm{e}-04)\end{array}$ & $\begin{array}{l}-0.002 \\
(0.001)\end{array}$ & $\begin{array}{l}3.3 \mathrm{e}-04^{*} \\
(1.7 \mathrm{e}-04)\end{array}$ \\
\hline Year: 2002/03 & $\begin{array}{l}0.015 \\
(0.023)\end{array}$ & $\begin{array}{l}-0.001 \\
(0.003)\end{array}$ & $\begin{array}{c}0.014 \\
(0.023)\end{array}$ & $\begin{array}{l}-0.001 \\
(0.003)\end{array}$ \\
\hline Year: 2004/05 & $\begin{array}{l}-0.026 \\
(0.026)\end{array}$ & $\begin{array}{c}-0.006^{* *} \\
(0.003)\end{array}$ & $\begin{array}{l}-0.026 \\
(0.026)\end{array}$ & $\begin{array}{c}-0.006 * * \\
(0.003)\end{array}$ \\
\hline Year: 2006/07 & $\begin{array}{l}-0.016 \\
(0.027)\end{array}$ & $\begin{array}{l}-0.002 \\
(0.003)\end{array}$ & $\begin{array}{l}-0.016 \\
(0.027)\end{array}$ & $\begin{array}{l}-0.002 \\
(0.003)\end{array}$ \\
\hline Year: 2008/09 & $\begin{array}{c}-0.082 * * * \\
(0.030)\end{array}$ & $\begin{array}{l}-0.002 \\
(0.004)\end{array}$ & $\begin{array}{c}-0.081 * * * \\
(0.030)\end{array}$ & $\begin{array}{l}-0.002 \\
(0.004)\end{array}$ \\
\hline Year: 2010/11 & $\begin{array}{c}-0.104^{* * *} \\
(0.033)\end{array}$ & $\begin{array}{c}3.3 \mathrm{E}-04 \\
(0.004)\end{array}$ & $\begin{array}{c}-0.104^{* * *} \\
(0.033)\end{array}$ & $\begin{array}{c}3.3 \mathrm{E}-04 \\
(0.004)\end{array}$ \\
\hline Rho & 0.38 & 0.25 & 0.38 & 0.25 \\
\hline Predicted Probability & 0.47 & 0.95 & 0.47 & 0.95 \\
\hline$N$ & 4,710 & 36,312 & 4,710 & 36,312 \\
\hline $\begin{array}{l}\text { the effect of one SD increase } \\
\text { in Tangible/Affection }\end{array}$ & $3.62 \%$ & $0.33 \%$ & $4.38 \%$ & $0.24 \%$ \\
\hline
\end{tabular}

Note: SD of Tangible for the two samples: 3.40 and 3.16. SD of Affection for the two samples: 2.57 and 2.20. All other independent variables suppressed for brevity. 